\title{
Las ideas externas en las doctrinas militares latinoamericanas de la guerra fría
}

\author{
External Ideas in the Latin American \\ Military Doctrines of the Cold War
}

\author{
Laura Sala* \\ (D) https://orcid.org/0000-0003-2463-0931 \\ Universidad Nacional de José C. Paz \\ Grupo de Estudios sobre Centroamérica (IEAlC-UBA), Argentina \\ laurasala@hotmail.com.ar
}

Resumen: Este artículo realiza una lectura crítica de la literatura que aborda las doctrinas militares durante la guerra fría en América Latina. Recorre una serie de trabajos sobre la Doctrina de Seguridad Nacional y la Doctrina de la Guerra Revolucionaria, en América Latina. Propone que esos textos se apoyan en una serie de supuestos -la mayoría de las veces implícitos- sobre el rol de los vínculos y las ideas externas en la elaboración de las mismas. A partir de allí los clasifica en tres grandes enfoques o momentos: 1) aquel que

* Doctora en Ciencias Sociales (UBA), magíster en Estudios Latinoamericanos (UNSAM) y Socióloga (UBA). Es becaria posdoctoral del Consejo Nacional de Investigaciones Científicas y Técnicas (CONICET) con sede en el Instituto de Estudios de América Latina y El Caribe (IEALC) de la Universidad de Buenos Aires. Es docente regular de la Universidad Nacional de José C. Paz. Integra el Grupo de Estudios sobre Centroamérica (IEALC-UBA) (http://geca.sociales.uba.ar/). Trabaja con herramientas de la sociología histórica, la antropología y la sociología política. Sus temas abordan los procesos de violencia política en Centroamérica, las relaciones entre las Fuerzas Armadas sur y centroamericanas y las doctrinas militares durante la guerra fría; la guerra fría y los procesos transnacionales en ese periodo en América Latina.

cómo citar: Sala, L. (2021). Las ideas externas en las doctrinas militares latinoamericanas de la guerra fría. Secuencia (111), e1946. Dor: https://doi.org/10.18234/secuencia.v0i111.1946

c) Esta obra está protegida bajo una Licencia Creative Commons Atribución-NoComercial 4.0 Internacional. 
enfatiza en la difusión estadunidense; 2) el que focaliza en la complejidad del proceso de exportación-importación, y 3) el que postula la idea de circulación transnacional. Finalmente, presenta otra forma de abordaje a partir de los conceptos de circulación-recepción.

Palabras clave: Doctrina de Seguridad Nacional; Doctrina de la Guerra Revolucionaria; circulación de ideas; doctrinas militares; guerra fría.

Abstract: This paper makes a critical reading about the studies on military doctrines during the cold war in Latin America. It goes through significant works on the National Security Doctrine and the Revolutionary War Doctrine, in Latin America. It proposes that this literature is supported by a series of assumptions -implicit- about the role of external links and ideas in their elaboration. The paper classifies it into three major approaches: 1 ) that which emphasizes North American broadcasting; 2) the one that focuses on the complexity of the export-import process and 3) the one that postulates the idea of transnational circulation. Finally, it proposes another approach based on the concepts of circulation-reception.

Keywords: National Security Doctrine; Revolutionary War Doctrine; circulation of ideas; military doctrines; cold war.

Recibido: 28 de enero de 2021 Aceptado: 14 de julio de 2021

Publicado: 19 de octubre de 2021

\section{INTRODUCCIÓN}

T as Fuerzas Armadas protagonizaron la escena política latinoamericana Ldurante la segunda parte del siglo xx. Los años sesenta vieron desplegarse dictaduras militares con características relativamente similares a lo largo de la región. Dada la larga historia de militarismo, estas se nombraron inicialmente como "nuevas" dictaduras o "neomilitarismo" en función de la novedad que presentaban en sus formatos políticos. Con algunas excepciones, las Fuerzas Armadas asumieron el control del aparato estatal en tanto institución, y tra- 
taron de evitar los personalismos que caracterizaron a las dictaduras militares previas. Todas asumieron un carácter represivo inédito en la región. ${ }^{1}$ La intervención política de los militares y el desarrollo de un proceso represivo sin parangón se configuraron en un contexto de crisis de dominación, marcado por la profundidad de las demandas sociales de cambio y la canalización de patrones militares en el Estado y en la cultura política. La especificidad de estos procesos, no obstante, se encuentra en las características que asumieron las Fuerzas Armadas como instituciones del Estado en ese contexto. Entre los primeros trabajos en esta dirección se encuentra el de José Nun (1966) que muestra las grandes transformaciones de las instituciones militares en la guerra fría para dar cuenta de las novedades del fenómeno, y el de Luis A. Costa Pinto (1972) que identificó las características fundamentales de la emergente racionalidad militar que más tarde se llamó Doctrina de Seguridad Nacional (Leal Buitrago, 2003, p. 82).

Los trabajos pioneros sobre las instituciones militares en estos años como los de Richard Adams $(1968,1973)$ en torno al caso guatemalteco, Víctor Villanueva (1972) sobre las Fuerzas Armadas peruanas, Frederick Nunn (1976) sobre las chilenas, Alfred Stepan $(1971,1973,1978)$ en torno a los militares de Brasil y Perú, José Luis de Imaz (1964), Robert Potash $(1985,1986)$ y Alain Rouquié $(1981,1982)$ sobre la relación entre el Ejército y la política en Argentina, lograron caracterizar la dinámica interna y organizacional de las Fuerzas Armadas. Así surgieron nuevas hipótesis que reposicionaron al actor militar y sus procesos internos dentro de las variables explicativas de los "nuevos militarismos", y a una complejización de los argumentos que ponían todo el peso explicativo del accionar militar en las dinámicas históricas impersonales o "sistémicas" según la caracterización de Fernando Bustamante (1986) y Paula Canelo (2008). ${ }^{2}$

${ }^{1}$ Por ejemplo: Brasil (1964-1985), Argentina (1966-1973 y 1976-1983); Bolivia (1971-1978 y 1980-1982), Uruguay (1973-1984), Chile (1973-1990), Guatemala (1963-1966 y 1982-1985).

${ }^{2}$ Paula Canelo (2008), siguiendo a Fernando Bustamante (1986), caracteriza la producción académica latinoamericana sobre las Fuerzas Armadas a partir de identificar dos grandes líneas de reflexión: la denominada "corriente sistémica" o "funcional teleológica" (Bustamante, 1986), que supone la existencia de una lógica social que funciona impersonalmente y al margen de los intereses, deseos y la propia comprensión de los actores, y la "corriente del actor" que centra su atención en los actores sociales, fundamentalmente en los intereses, valores, ideologías y objetivos de las Fuerzas Armadas. Dentro de esta corriente se sitúa la "perspectiva organizacional" que enfatiza en los aspectos organizacionales y enmarca las acciones de las Fuerzas Armadas como producto de determinado tipo de "socialización restringida", y la "perspectiva 
De acuerdo con Stepan (1971), el fuerte contenido doctrinario es una de las características diferenciales de estos procesos (p. 173). Más tarde, Ernesto López (1987) señaló que el "comportamiento político de los militares está, en importante medida, asociado a las doctrinas que prevalecen en el interior de las instituciones armadas" (p. 15). Para el sociólogo guatemalteco Gabriel Aguilera Peralta (1989) "entender cómo piensan es entender cómo actúan" (p. 20). En ese marco, el estudio de las doctrinas militares en la guerra fría fue ganando terreno progresivamente entre las ciencias sociales y la historia reciente. A partir de allí, se fue desarrollando un campo fructífero de estudios cuyo eje giró, fundamentalmente, en torno a la Doctrina de Seguridad Nacional (en adelante DSN) y con posterioridad, a la Doctrina de la Guerra Revolucionaria (en adelante DGR) vinculadas a la influencia estadunidense y francesa, respectivamente. Mucho menos se estudió la "influencia" de las doctrinas contrainsurreccionales británicas. ${ }^{3}$ Luego se daría énfasis a la Doctrina de la Guerra de Baja Intensidad, pero vinculada con el fin de la guerra fría.

¿Cómo se aborda, en dicha literatura, la cuestión de las ideas externas en las doctrinas militares latinoamericanas de la guerra fría?, ¿cómo se entiende el proceso de circulación de ideas doctrinarias?, ¿cómo se plantea la relación entre las Fuerzas Armadas locales y extranjeras en el contexto de la guerra fría?, ¿cómo se interpreta, en general, la relación interno-externo? Estas son las preguntas que este trabajo intenta responder. Estas interrogantes surgieron en la investigación de mi tesis doctoral en la que pude comprobar, desde una aproximación sociológico-histórica, la circulación de ideas doctrinarias entre las Fuerzas Armadas argentinas y centroamericanas en el periodo 1978-1982, y su recepción por parte de las Fuerzas Armadas guatemaltecas. Este hallazgo parecía complejizar la idea comúnmente aceptada en torno a las doctrinas que guiaron el accionar de los militares de la región en la guerra fría. Esto es, doctrinas difundidas por los países centrales de occidente, especialmente Estados Unidos, y en menor medida Francia, con el objetivo de adoctrinar a los militares de la región en la defensa del "mundo

instrumental" que entiende a las Fuerzas Armadas como "instrumento" o "brazo armado" al servicio de otros grupos o clases sociales. Esta última se diferencia de la "corriente sistémica" en que parte de un supuesto metodológico individualista, ya que destaca los intereses de actores sociales concretos (Canelo, 2008).

${ }^{3}$ Sobre la doctrina británica, véase Dixon (2012) o los propios autores británicos de la contrainsurrección colonial y poscolonial como Robert Thompson y su obra de 1966 Defeating communist insurgency: Experiences from Malaya and Vietnam. 
occidental" frente al comunismo. Ello motivó la necesidad de sistematizar el conocimiento generado sobre el tema en un "estado de la cuestión" cuyos puntos centrales se presentan en este artículo. Para su elaboración se construyó un corpus documental a partir de una selección de textos cuyo periodo temporal se extiende desde finales de los años setenta, cuando irrumpen los estudios sobre la DSN, hasta la actualidad. El corpus está compuesto por textos que analizan la DSN como fenómeno regional, así como de estudios sobre las doctrinas en diversos casos nacionales (trabajos sobre DSN y DGR en el nivel local), especialmente los referidos a los casos argentino y brasileño -donde se registra mayor producción-y guatemalteco.

Los textos fueron interpelados a partir de las interrogantes planteadas previamente. En función de ello, clasificamos la literatura en tres grandes enfoques o momentos: 1) aquel que enfatiza en la difusión estadunidense; 2) el que focaliza en la complejidad del proceso de exportación-importación, y 3) el que postula la idea de circulación transnacional. Proponemos un cuarto enfoque anclado en los conceptos de "circulación-recepción" basado en mi trabajo previo sobre la circulación de "ideas contrasubversivas" entre las Fuerzas Armadas argentinas y centroamericanas y su recepción por los militares guatemaltecos. Cada bloque o momento representa un enfoque particular en lo tocante a: la concepción de los orígenes de esas ideas; la forma en la que circularon en la región, y los modos de adecuación de las mismas a las doctrinas locales. Planteamos que estas diferencias se apoyan en una serie de premisas la mayoría de las veces implícitas- sobre el rol de los vínculos internacionales y las ideas externas en el proceso de elaboración doctrinaria en el contexto de la guerra fría, cuya clarificación puede aportar al estudio de las doctrinas militares. Como se muestra a lo largo del artículo, estas premisas tienen que ver, por un lado, con la forma en que se concibe al actor militar, a sus vínculos con otras fuerzas armadas y a sus relaciones con la sociedad de la que forman parte; en segundo lugar, con la manera en que entienden los procesos de circulación de ideas y, finalmente, con la concepción de la guerra fría en la que abrevan y de los vínculos internacionales desatados en este contexto. Estos tres elementos, a pesar de su distinción analítica, se encuentran estrechamente vinculados.

Nuestra intención es ordenar el campo de estudios a partir de lo que consideramos diversos enfoques epistemológicos y aportar -desde allí- a la discusión teórica e histórica sobre las doctrinas militares de la guerra fría latinoamericana. Dejamos para otra instancia el análisis riguroso de los contextos de emergencia de cada enfoque y de las corrientes teóricas que los integran. 
La organización del texto empieza por una caracterización general de la DSN y de la DGR según los estudios analizados, para luego adentrarnos en el estado de la cuestión que proponemos. En esta segunda parte del texto se describen cada una de las tres perspectivas identificadas y se propone un cuarto enfoque. Finalmente, se formulan las reflexiones concluyentes.

\section{LA DOCTRINA DE SEGURIDAD NACIONAL Y LA DOCTRINA DE LA GUERRA REVOLUCIONARIA}

El estudio de la DSN surge, fundamentalmente, a partir de la búsqueda de explicaciones al nuevo tipo de intervención política de los militares, al "nuevo militarismo". Hacia 1977, Mauricio Ruz (1977) comentaba sobre la "profundización del debate" en torno a la DSN y sobre "su extensión más allá de los círculos puramente castrenses a medios intelectuales y eclesiásticos". En los años finales de esa década, la DSN era la gran novedad que requería ser estudiada. Desde las ciencias sociales proliferaron los escritos sobre esta famosa "doctrina" entendida como un fenómeno de alcance regional. Francisco Leal Buitrago (2003) señaló que la DSN "se convirtió en una especie de 'razón social' o rótulo usado por variados sectores sociales para identificar [...] a una amplia gama de acciones llevadas a cabo por los militares de la región" (p. 75). Entre los trabajos fundacionales del estudio de la DSN en América Latina se cuentan los de Jaime Rojas y José Antonio Viera-Gallo (1977), Mauricio Ruz (1977), Joseph Comblin (1976, 1978, 1979), Manuel A. Garretón (1978), Manuel A. Garretón y Genaro Arriagada (1978), Andrés Nina (1979), Roberto Calvo (1979), Alberto Methol Ferré (1979), Jorge Tapia Valdés (1980). Trabajos posteriores de gran relevancia fueron los de David Pion-Berlin (1989), Luis Maira (1990); Édgar de Jesús Velásquez Rivera (2002) y la producción de Francisco Leal Buitrago (2002, 2003).

Todos estos trabajos fueron construyendo un consenso generalizado respecto a la DSN como fundamento ideológico de las dictaduras de los años sesenta y setenta en América Latina. El énfasis de esta literatura en la caracterización de la DSN está puesto en las ideas de carácter político-ideológico que la constituyen, entre las que se distinguen una serie de conceptos filosóficos y otros de tipo operativos: una idea de la guerra fría basada en la "bipolaridad del mundo" asimilada con el conflicto este-oeste; una concepción organicista de la "nación" y el "Estado", y una idea nueva de guerra centrada en la noción de "enemigo interno" configurado a partir de la penetración interna 
del comunismo favorecida por el subdesarrollo y la pobreza. Por otro lado, el concepto de seguridad nacional entendido de manera general como la capacidad de lograr, a partir de la definición de una "estrategia nacional", la consecución de los "objetivos nacionales" limitando la acción del "enemigo interno". Las Fuerzas Armadas, en este marco doctrinario, se erigen como las más aptas para llevar adelante la misión. Jorge Tapia (1980) concluye que la trascendencia de esta doctrina deriva "de su contenido político y del impacto que ha tenido dentro de los países Latinoamericanos en lo que se refiere al papel de las fuerzas armadas" (p. 137). Para Tapia, la DSN no es una doctrina militar para la guerra, "sino una doctrina política para los militares, gestada en Estados Unidos y dirigida a motivar la intervención pseudo-autónoma de los militares latinoamericanos" (p. 99). Leal Buitrago (2003) concluye en esa misma línea que la DSN en América Latina "fue, ante todo, un planteamiento ideológico y político que responde a una racionalidad mecánica y ante todo militar, que fue ejecutada por medio de golpes de Estado" (p. 85). Todos estos trabajos centran su mirada en el Cono Sur de la región. En ellos, los aspectos técnicos militares de la doctrina no tienen un lugar destacado.

En esa misma línea han proliferado una enorme cantidad de análisis sobre la DSN que indagan en la relación entre doctrina y comportamiento político de los militares para pensar casos nacionales. Para el caso argentino, por ejemplo, destacan los trabajos de Ernesto López (1985, 1987), Alicia García (1991), Moisés Cherñavsky (1993), Guillermo Monkman (1992) y, entre los más nuevos, se destacan los trabajos de Esteban Pontoriero (2017), María Cecilia Míguez (2013), entre muchos otros.

Con posterioridad, logró un desarrollo significativo el estudio de la llamada Doctrina de la Guerra Revolucionaria de origen francés en las doctrinas militares latinoamericanas. Varios trabajos sobre la DSN la habían incorporado entre sus antecedentes (Comblin, 1979; Tapia Valdés, 1980, entre otros). Jorge Chateau (1983) la caracteriza con detalle a partir del análisis de la obra de Roger Trinquier, pero la concibe como parte integrante de la DSN ensamblada en Estados Unidos. Considera que adquiere "importancia en América Latina cuando Estados Unidos, luego de la revolución cubana, empieza a promover la idea y también la capacitación y los recursos de la "counter insurgency" (p. 1). El avance en la investigación sobre la DGR y el acceso a nuevas fuentes reveló, sin embargo, que esta "corriente doctrinal" tuvo un peso propio y estatus diferenciado de la orientación doctrinaria estadunidense en la región. Rodrigo Nabuco de Araujo (2011) plantea, incluso, que la doctrina francesa 
"es la matriz militar de los regímenes dictatoriales sudamericanos, a diferencia de la retórica militante de la década de 1970, que denuncia el control estadounidense sobre los ejércitos latinoamericanos" (p. 62). Se han señalado diferencias entre ambas "doctrinas" tanto en su dimensión política como en la cuestión táctica-militar que plantean. Respecto a las cuestiones técnico-militares o de táctica-militar, la DGR es más específica. Por otro lado, como indicó tempranamente Alain Rouquié (1982), el enfoque francés permitía una internacionalización de los conflictos locales en clara oposición al enfoque estadunidense de la DSN, en el cual la conflictividad social y el incremento de la violencia respondían a cuestiones internas como la pobreza y el subdesarrollo que reinaban en Latinoamérica (pp. 156-159). Mientras la corriente francesa hacía hincapié en un enfoque ideológico y global del fenómeno de la insurgencia, la influencia de Estados Unidos se ejercía como justificación racional de la intervención militar en la seguridad y el desarrollo internos y subrayaba la necesidad de una defensa colectiva del hemisferio occidental contra el expansionismo comunista (Armony, 1999, p. 35).

La DGR y la "influencia" francesa alcanzaron popularidad con la investigación periodística y la película Los escuadrones de la muerte. La Escuela Francesa, de Marie Monique Robin. Los estudiosos acuerdan en que los componentes de esta doctrina derivan de la idea de "guerra revolucionaria" aprendida y teorizada por los franceses en función de sus experiencias en Vietnam (1946-1954) y Argelia (1954-1962) y de los textos de Mao Tse Tung. Como señala el historiador canadiense Marc Drouin (2017), la teorización sobre este tipo de conflicto en el contexto de la guerra fría fue una de las principales contribuciones francesas al arte y a las ciencias de la guerra en el siglo xx. ${ }^{5} \mathrm{La}$ lectura francesa de esta nueva forma de guerra se basaba en una serie de proposiciones teóricas básicas. En principio, concibe al mundo como dividido en dos partes: el "mundo comunista" y el "mundo libre". El campo de batalla ya no es el territorio, sino la "población"; el enemigo comunista se infiltra en la población para ganar sus "mentes y corazones" y lograr apoyo en su guerra contra el orden establecido. ${ }^{6}$ En la población es donde el enemigo extrae

${ }^{4}$ Traducción propia de "Tout d'abord, la doctrine française est la matrice militaire des régimes dictatoriaux sud-américains, contrairement aux discours militants des années 70 qui dénoncent la mainmise états-unienne sur les armées latino-américaines".

${ }^{5}$ Para valorar la contribución francesa, véase Thomas Rid y Thomas Keaney (2010).

${ }^{6}$ Según Christian Olsson (2009) la expresión conquistar "los corazones y los espíritus de la población”, es generalmente atribuida a Sir Gerard Templer, responsable de Malasia durante 
su fuerza y se reproduce. El enemigo deja de ser un ejército extranjero para constituirse en un "enemigo interno". Las fronteras que separan a los bandos, entonces, ya no son geográficas sino "ideológicas". Esta interpretación de la guerra revolucionaria lleva al planteo de tácticas y estrategias de guerra basadas en el control y el terror. En principio, la sociedad en su conjunto es objeto de sospecha y por ende se transforma en el objetivo de las operaciones contrasubversivas. En términos territoriales, plantea la necesidad de reconocer las zonas afectadas a través de una delimitación concreta. Al extenderse el estado de sospecha a toda la sociedad, se hace necesario ampliar los servicios de informaciones y redireccionar su accionar hacia la nueva hipótesis de conflicto. La población, combatiente y no combatiente, se convierte en el principal proveedor de información. Para extraerla, se avala el uso de la tortura. Asimismo, surge la necesidad de involucrar otro tipo de "armas" no militares en la guerra: la acción psicológica y la acción cívica. Con estas "armas" se debe disputar las "mentes y corazones", lograr la adhesión al gobierno y a las Fuerzas Armadas para "quitarle el agua al pez".

Si bien desde los momentos iniciales del estudio de las doctrinas militares en la guerra fría se señaló la influencia de la DGR en América Latina, su análisis más riguroso se desarrolló con posterioridad y ha cobrado auge en las últimas décadas. Los casos argentino y brasileño han liderado la investigación. Para el primero, destacan las investigaciones de Samuel Amaral (1998), Marie Monique Robin (2014), Mario Ranalletti (2011, 2018), Gabriel Périès (1999, 2009a, 2009b), Daniel Mazzei (2002), Esteban Pontoriero (2017). Para el caso brasileño, Rodrigo Nabuco de Araujo (2012, 2016), Martins Filho (2008, 2012) y Mariana Joffily (2008). Las investigaciones recientes de Marc Drouin (2017) en el marco de su peritaje judicial para casos de delitos de lesa humanidad en Guatemala han revelado la significación que la DGR tuvo entre los militares guatemaltecos, plasmadas en el Manual de Guerra Contrasubversiva.

Con excepción de Nabuco de Araujo, quien argumenta sobre la importancia de la DGR en la intervención militar en el ámbito político, la mayoría de los trabajos están enfocados en relacionar esta Doctrina con los procesos represivos. Enfatizan en las cuestiones técnico-militares que proveyó la Doctrina a las

la campaña contrainsurreccional del Malayan Emergency (entre 1948-1960). Sin embargo, parece que fue utilizada previamente en la pacificación de las tribus Pashtún (afgano étnico) en la zona de la North Western Frontier del Raj británico, y de modo más específico del Waziristán y Beluchistán de los años 1920. 
fuerzas armadas latinoamericanas con las que estuvo en contacto. Existe un consenso generalizado entre quienes estudian la influencia francesa respecto a su fuerte impacto en el desarrollo de los mecanismos de inteligencia y la táctica de la tortura entre los militares y agentes de seguridad. No obstante, Mario Ranalletti (2018) ha propuesto recientemente matizar ese consenso respecto de la influencia en las tácticas de tortura para el caso argentino, y profundizar en la "adecuación local" y la "reinterpretación" de estas doctrinas considerando la influencia que sobre los militares tuvieron el catolicismo intransigente y la extrema derecha. En esa línea, se afirma el trabajo de Federico Finchelstein (2016) sobre los orígenes ideológicos de la "guerra sucia" en Argentina.

Hacia los años ochenta cobró relevancia la llamada Doctrina de la Guerra de Baja Intensidad (DGBI) o "conflicto de baja intensidad" -low intensity conflict, LIC- para explicar los conflictos aún vigentes en América Central, particularmente en El Salvador y Nicaragua y, en menor medida, en Guatemala. Lo que se subraya en estos casos no es la incorporación de la DGBI en la doctrina militar de estos países, sino su desarrollo entre la oficialidad estadunidense para justificar la intervención directa contra el sandinismo en Nicaragua y el apoyo al gobierno salvadoreño contra el movimiento revolucionario liderado por el Frente Farabundo Martí de Liberación Nacional (FMLN) (Kornbluh, 1990; Siegel y Hackel, 1990). ${ }^{7}$

${ }^{7}$ Los partidarios de la DGBI criticaban la política militar de Ford y Carter orientada a la amenaza convencional de tropas soviéticas en Europa Central y proponían una vuelta a la "guerra de contrainsurgencia" de Kennedy con algunos avances en su concepción. Esta doctrina empieza a formularse con la llegada de Reagan al gobierno estadunidense en 1981. Así como Kennedy apoyó el viraje de prioridades desde la guerra convencional a la guerra contrainsurgente, Reagan volvió a hacerlo hacia la guerra de baja intensidad. Michael Klare y Peter Kornbluh (1990) relacionan la DGBI con la búsqueda por parte de Reagan de un mecanismo aceptable de intervención -luego del "síndrome de Vietnam"- en los países del Tercer Mundo y con su anhelo de restaurar el dominio de Estados Unidos en aquellas zonas donde peligraba: un nuevo intervencionismo. Según la definición acordada por oficiales estadunidenses de alto rango, la DGBI refiere a "una lucha político-militar limitada con fines políticos, sociales, económicos o psicológicos. Suele ser prolongada e incluye desde las presiones diplomáticas, económicas y psicosociales hasta el terrorismo y la insurgencia (combinando operaciones de baja visibilidad o clandestinas, de evasión y escape, de sabotaje, etc.). En general, la DGBI está circunscripta a un área geográfica y a menudo se caracteriza por la restricción en materia de armas, tácticas y nivel de violencia" (citado en Klare, 1990, p. 69). Como sostienen Bonavena y Nievas (2006), la amplitud de esta definición la hace poco operativa en términos conceptuales, no obstante, concuerdan con Klare y Kornbluh (1990) en que su postulación es un intento de dotar a las tropas regulares de una "ideología de guerra" que avale las intervenciones militares (p. 362). 


\section{LOS VÍNCULOS Y LAS IDEAS EXTERNAS EN EL PROCESO DE ELABORACIÓN DE LAS DOCTRINAS MILITARES EN LA GUERRA FRÍA}

Ernesto López señaló en 1987 que la cuestión de las influencias externas en las doctrinas militares era una "cuestión tan recurrida como imprecisa en el estudio de los orígenes de la DSN" (p. 13). En esa línea, Cristian Buchrucker (1994) sostuvo, respecto de la DSN, que no hay un acuerdo general cuando se trata de desmenuzarla en sus componentes y asignarles una jerarquía en relación con su procedencia. Todos los textos que analizamos en este artículo prestan especial atención a los orígenes de las ideas que constituyen las doctrinas militares y a las vías de transmisión de las mismas. A partir de indagar cómo abordan la cuestión de las ideas externas en las elaboraciones doctrinarias, es posible clasificar la bibliografía en tres bloques, cada uno de los cuales se corresponde con un momento particular en el desarrollo de los estudios sobre las doctrinas militares. El primero integra la bibliografía que inició los estudios de la DSN en tanto fenómeno regional explicativo de los nuevos militarismos, cuyo énfasis estuvo en el rol de Estados Unidos como difusor de la misma en las Fuerzas Armadas latinoamericanas. El segundo bloque agrupa a los estudios que se interesan por comprender el proceso de exportación-importación de las ideas doctrinarias. ${ }^{8}$ Dentro de este grupo se integran los trabajos críticos sobre la DSN en el nivel regional, los que estudiaron la DSN desde el ámbito local y aquellos que analizaron la influencia francesa de la DGR. El tercer bloque de trabajos es incipiente y propone una circulación transnacional de las doctrinas militares. Cada bloque o momento representa un enfoque particular en lo tocante a: la concepción de los orígenes de esas ideas; a la forma en que circularon en la región, y los modos de adecuación de las mismas a las doctrinas locales.

${ }^{8}$ Con "ideas doctrinarias" nos referimos a aquellas vinculadas a las hipótesis de guerra y a la caracterización de los conflictos vigentes o probables de una nación (sus causas, enemigos y aliados, formas de enfrentarlos, etcétera). 


\section{La difusión estadunidense ${ }^{9}$}

Un planteo paradigmático de esta perspectiva es el de Joseph Comblin (1979) para quien la DSN "es una doctrina americana. Los latinoamericanos no han inventado nada. Aún más, han modificado muy poco la doctrina que recibieron completamente hecha de los Estados Unidos" (p. 15). La DSN en la región sería el resultado de una transposición casi mecánica de la doctrina militar desde el centro hacia la periferia. Esta ha sido la mirada dominante entre los primeros estudios sobre la DSN en clave regional (Comblin, 1979; Maira, 1990; Nina, 1979; Tapia Valdés, 1980; Velásquez Rivera, 2002, entre otros). El origen externo e impuesto de la doctrina a las Fuerzas Armadas latinoamericanas implica, desde esta visión, una "desnacionalización de la vida social y política" (Lozada, Viaggio, Zamorano y Barcesat, 1985). Si bien se reconocen componentes provenientes de Francia, Alemania, y en algunos casos de la geopolítica sudamericana, es Estados Unidos el gran ensamblador y difusor de la DSN. Esta idea ha sido abonada por la academia estadunidense -militar y civil-cuya producción se ha abocado a argumentar en torno a la centralidad de su influencia en la formación doctrinaria de los militares latinoamericanos y sus consecuencias en el ámbito político (Fitch, 1977; Fox, 2001; Gill, 2004; Shirley, 1997; Wolpin, 1973, entre otros). Se señalan tres "vías de transmisión" de la "doctrina" hacia Latinoamérica: las reuniones de jefes militares, los programas de ayuda militar o venta de armas, y el entrenamiento de oficiales y otros especialistas en las escuelas militares estadunidenses. La latinoamericanización de la DSN se explica, de esta manera, por un factor externo a la región: la política estadunidense en la guerra fría.

Estos trabajos construyen su argumentación enfocando en el centro del análisis la política estadunidense para la región más que en la propia dinámica de los países latinoamericanos. Sus fuentes suelen ser documentos oficiales desclasificados de organismos gubernamentales estadunidenses. Esta perspectiva permitió comprender la política de Estados Unidos para la región y valorar la enorme significación que tuvo en el desarrollo institucional castrense. No obstante, opaca otras cuestiones de relevancia como las producciones ideológicas nacionales, los procesos internos y los objetivos con que los actores locales "recibieron" la propuesta ideológica de la seguridad nacional estadunidense.

\footnotetext{
${ }^{9}$ Las ideas de este apartado se retomaron de Sala (en prensa).
} 
Desde esta perspectiva, las Fuerzas Armadas latinoamericanas parecen haber incorporado de forma pasiva, acrítica y textual un bloque de ideas proveniente del país del norte y haberse convertido, con ello, en el "martillo" de Estados Unidos para mantener su dominación en la región. Si bien este enfoque parte de concepciones que otorgan centralidad al actor militar en la explicación de los militarismos en tanto reconoce la importancia de su doctrina, no deja de considerarlo de manera instrumental al servicio de otros actores. Se ubica en lo que Paula Canelo (2008) denomina la "perspectiva instrumental" dentro de la "corriente del actor".

Estas lecturas extreman los planteos que focalizan en la "dependencia militar" latinoamericana. ${ }^{10}$ La dependencia adquiere rasgos mecanicistas. Se explica, en parte, por su concepción de la guerra fría, según la cual la región se constituye en un escenario de batalla subordinado a los mandatos e intereses de las potencias en pugna, y los actores en correas de transmisión de las mismas. La guerra fría absolutiza las dependencias, imposibilita toda resistencia a las prácticas imperialistas y subsume a los países latinoamericanos, sin opción, en el conflicto este-oeste. Desde esta mirada, los "nuevos militarismos" y la DSN son vistos como una ruptura histórica. Las líneas de continuidad, los determinantes del largo plazo histórico, quedan subordinados ante la magnitud del cambio en la forma de organización del orden político y la novedad que significa, desde esta perspectiva, su fundamento ideológico: la DSN. Ruptura, también, por su dimensión "desnacionalizadora".

Esta perspectiva tiene un peso importante en los trabajos sobre la DSN en Centroamérica. Edelberto Torres Rivas (2001) afirma que, aunque la Alianza para el Progreso implicó más empréstitos a América Central y aumentó la legitimidad de la idea de la reforma agraria y el cambio estructural, "también dio lugar a un aumento de la ayuda militar, en particular para Guatemala y Nicaragua, e introdujo la doctrina de la seguridad nacional" (p. 40). Prudencio García (2005) señala que esta doctrina, "como factor arrollador procedente del exterior, fruto directo y envenenado de la Guerra Fría, ejerció en el caso de Guatemala un efecto más demoledor que en cualquier otro lugar del continente americano". Para el analista militar la DSN constituyó "por su

10 En torno al enfoque clásico sobre la dependencia militar latinoamericana, véase Veneroni (1973). Otro enfoque que matiza y problematiza la relación de dependencia militar con Estados Unidos se encuentra en los artículos reunidos en "La dependencia militar latinoamericana” del número 4 ( $2^{\circ}$ semestre de 1978) de Cuadernos Semestrales. Estados Unidos. Perspectiva Latinoamericana. 
origen extranjero" uno de los más nocivos ingredientes de lo que denomina el vector internacional del genocidio. El sociólogo colombiano Francisco Leal Buitrago (2003), a pesar de considerar que la DSN es una variante, propia de América del Sur, de la categoría política "seguridad nacional" desarrollada en Estados Unidos, postula que en Centroamérica no hubo un desarrollo propio de la DSN, sino que se adoptaron varios de los principios contenidos en la concepción estadunidense de "estado de seguridad". Para estos países, sostiene, Estados Unidos elaboró en los años ochenta la Guerra de Baja Intensidad que se puso en marcha a partir del gobierno de Ronald Reagan (pp. 80-81).

\section{El proceso de importación-exportación}

La segunda perspectiva enfatiza en el proceso de exportación-importación de ideas para pensar la doctrina. Esta mirada no considera a las ideas de origen externo como "impuestas" a las Fuerzas Armadas locales. Mauricio Ruz (1977) ironizó, tempranamente, sobre ello: "Todo pasaría como si de repente una determinada concepción surgiera en otro contexto e, imponiéndose desde fuera, tuviera la capacidad de regular la sociedad y dictar las acciones de sus sostenedores o promotores" (p. 424). ${ }^{11}$ En su trabajo sobre la DSN en El Salvador, Lucrecia Molinari (2011) afirmó en tono crítico que la "DSN no se aplica sobre una tabla rasa, sino en una sociedad específica con una historia determinada y que está atravesando, en el momento de la 'importación', una coyuntura determinada" (p. 2). Desde esta perspectiva, las Fuerzas Armadas aparecen con mayor autonomía respecto de los centros de poder y con una trayectoria interna histórica que debe ser considerada. Se atiende a las condiciones locales que hicieron posible la vinculación. A diferencia de la perspectiva de la difusión estadunidense según la cual el solo vínculo con la fuerza armada imperial produciría cambios en la doctrina de las Fuerzas Armadas locales, en esta perspectiva las mediaciones son la clave de la explicación

${ }^{11}$ La sociología crítica latinoamericana planteó tempranamente ese tipo de críticas. El sociólogo boliviano, René Zavaleta Mercado (2015), por ejemplo, sostenía que desde la mirada de algunas teorías de la dependencia o el sistema mundo, "lo que ocurriría en América Latina, sobre todo en lo referido a su ultimidad política o carácter de la dominación, no sería sino el reflejo o la correspondencia hacia procesos, decisiones o impulsiones que vendrían de los centros determinativos del mundo" (p. 305). En el caso de Zavaleta, la falta en la que incurrían estas teorías se ubicaba en la poca consideración de las determinaciones nacionales. 
de los cambios doctrinarios. En estos trabajos, la guerra fría, como hecho que transforma a Latinoamérica en escenario de batalla de las dos grandes potencias, pierde la centralidad determinante que tiene en la perspectiva anterior. Se postula la necesidad de indagar en los aspectos internos y en su relación dialéctica con lo externo, "pues lo externo sólo alcanza su potencia cuando lo percibimos en su dialéctica con lo interno" (Methol Ferré, 1979, p. 229). Se enfatiza, a diferencia de la perspectiva de la difusión estadunidense, en a) las convergencias de las ideas foráneas con las creaciones locales o con otros universos ideológicos locales, $b$ ) en los procesos políticos, sociales y/o económicos internos, y $c$ ) en los intereses, trayectoria y/o disputas de los actores locales.

Si bien las tres dimensiones señaladas suelen estar presentes en los análisis incluidos en esta perspectiva, hay diferencias de énfasis en las explicaciones. Entre quienes prestan especial atención a las convergencias con las ideas locales, se encuentran trabajos críticos sobre la DSN en tanto fenómeno regional (Garretón, 1978; Methol Ferré, 1979; Pion-Berlin, 1989; Ruz, 1977). Estos trabajos reconocen una dimensión regional de la DSN, pero plantean una heterogeneidad de formulaciones a partir de las variantes en el enfoque prevaleciente de la Seguridad Nacional, concepto núcleo de la DSN. Según Ruz (1977) y Manuel Garretón (1978), la definición del problema de la seguridad nacional con base en las tensiones que marcaban las relaciones internacionales de América Latina -este-oeste (comunismo-anticomunismo) o norte-Sur (desarrollo-subdesarrollo)-, dieron lugar a las dos ramas de la DSN en América Latina. ${ }^{12}$ Brasil abrazó la primera tensión, mientras Perú se ubicó en la segunda. Más tarde, David Pion-Berlin (1989) señaló, en una línea similar, la existencia de variantes de la DSN a partir de diversas definiciones de "Seguridad Nacional", pero también de "Estado" y de "estrategia". En cada uno de estos aspectos hay diferencia entre una línea dura y una blanda. Mientras Comblin (1979), característico de la perspectiva de la difusión estadunidense, se preguntaba sobre la posibilidad de explicar las similitudes de los "nuevos militarismos" a partir de la DSN, Pion-Berlin (1989, p. 412) se preguntó por la posibilidad de explicar las diferencias entre los regímenes a partir de sus diferentes concepciones de la DSN. Ruz (1977), además de identificar una variabilidad en la definición del "problema de seguridad nacional", agrega una

${ }^{12}$ Es probable que "Mauricio Ruz" sea un nombre ficticio con el que su autor publica en el marco de la dictadura chilena. No hemos encontrado otro registro de textos de su autoría. 
diferenciación al considerar las convergencias en la DSN con otros universos ideológicos locales. Entre ellos destacó las concepciones nacionalistas en sus distintas versiones; el pensamiento social católico en las versiones tradicionales, y ciertas concepciones "tecnocráticas". Las diversas combinaciones expresan, según el autor, las alianzas entre sectores y grupos sociales; y constituyen las contradicciones de la DSN.

Entre quienes enfatizan en los intereses, trayectorias y disputas de las propias fuerzas armadas, se destacan algunos análisis en torno a la relación entre la doctrina militar de las Fuerzas Armadas latinoamericanas y la Doctrina de la Guerra Revolucionaria francesa. Aquí los intereses, preocupaciones y proyectos de los actores en sus respectivos contextos de acción cobran protagonismo explicativo. Marc Drouin (2017) plantea que "en su intento por vencer una insurgencia de izquierda”, el Ejército guatemalteco acudió a la experiencia francesa, y "adaptó lineamientos y métodos de una doctrina militar ya existente" (p. 185). Mario Ranaletti $(2011,2018)$ incorpora las "intenciones personales" de los actores receptores y las "dinámicas ideológicas internas" en la vinculación entre las instituciones armadas de Argentina y Francia, mientras Gabriel Périès (2009b) se preocupa por el proceso de adaptación del lenguaje para hablar de una "transposición" de la DGR en Argentina. Rodrigo Nabuco de Araujo (2011) considera las "afinidades electivas" entre las Fuerzas Armadas brasileñas y francesas. João Roberto Martins Filho (2008) destaca que el "proceso de importación" de las ideas francesas comienza por los intereses de los militares argentinos, primero, y luego brasileños. Luego de la segunda guerra mundial, estas instituciones buscaron por sí mismas -enfatiza el autor- una doctrina de guerra más adaptada a sus necesidades, lo que Estados Unidos no parecía ofrecer.

Estos trabajos problematizan la total hegemonía estadunidense que postulan los trabajos enmarcados en la perspectiva de la difusión estadunidense. Algunos proponen a la matriz doctrinaria francesa como la base de las doctrinas sudamericanas (Martins Filho, 2012; Nabuco de Araujo, 2011), otros plantean una temporalidad diferente en el predominio de una "influencia" u otra (Amaral, 1998; Llumá, 2003; Mazzei, 2002; Pontoriero, 2017; Ranalletti, 2011). Así, para el caso argentino, por ejemplo, Daniel Mazzei (2002) afirma que la "influencia francesa fue hegemónica" durante el periodo 1957-1962. Sostiene incluso que el Ejército argentino nunca utilizó la terminología estadunidense sobre "contrainsurgencia", sino que prevalecieron las categorías "guerra contrarrevolucionaria" y "lucha contra la subversión", utilizadas por el Ejér- 
cito francés. ${ }^{13}$ Mario Ranalleti (2011) postula a las postrimerías del gobierno de Perón en 1954 como la fecha de llegada de la noción de guerra revolucionaria a las Fuerzas Armadas argentinas a través de publicaciones especializadas de militares argentinos y traducciones. Las vías de transmisión contemplan no sólo las ofrecidas por el "exportador" de las ideas, sino también las gestionadas por la parte importadora. Tanto las misiones militares francesas o la formación de militares en Francia, como la importación de libros, artículos y sus traducciones y publicaciones en los órganos oficiales de las Fuerzas Armadas importadoras constituyen, en esta perspectiva, una vía válida de transferencia. Las fuentes de estos trabajos contemplan archivos locales y documentos oficiales de las Fuerzas Armadas latinoamericanas: revistas militares, manuales, reglamentos, boletines reservados, órdenes generales. Asimismo, se consideran archivos franceses de las respectivas diplomacias.

En esta perspectiva, y específicamente en los trabajos sobre la DGR, se nota una mayor preocupación por esclarecer la noción de "doctrina militar" que en los estudios anclados en la "difusión" donde predomina una similitud entre los conceptos de "doctrina militar" e ideología política. ${ }^{14}$ En este enfoque, la doctrina militar denota mayor especificidad. Se identifican aspectos políticos y otros de tipo técnico-militares, aunque en estrecha vinculación. En la mayoría de los casos que integran este enfoque, la doctrina es aquella que se encuentra inscrita en documentos oficiales socializados en la institución.

Muchos de los trabajos sobre doctrina en casos nacionales, aquellos que no tienen como objetivo principal indagar en la influencia de ideas foráneas, también pueden ubicarse en esta perspectiva en tanto que, para estudiar la doctrina local, mencionan las influencias externas aunque considerando las condiciones locales de posibilidad de su recepción. Estos contemplan especialmente, aunque no exclusivamente, los procesos políticos, sociales y/o económicos internos. En estos trabajos se intenta pensar lo ideológico en menor medida como un campo autosuficiente que en conexión con el mundo de los procesos sociales en el que se inserta. Un ejemplo que sobresale es el análisis de Ernesto López (1987) sobre el proceso de sustitución de la Doctrina de Defensa Nacional por la Doctrina de Seguridad Nacional en Argentina con el

${ }^{13}$ Germán Soprano (2018) ha argumentado sobre la continuidad en la formación básica, el perfeccionamiento en las academias militares y en la planificación anual de las unidades operativas del Ejército argentino de las doctrinas de guerra convencional, sin negar la gravitación de la DGR y la DSN.

${ }^{14}$ Véase al respecto, Sala (en prensa). 
objetivo de abordar el intervencionismo militar. López (1987) propone estudiar el modo en que la "oferta" estadunidense se cruzó con una "demanda" local: "cómo aparecieron en la sociedad actores dispuestos a asumirla, cómo la metabolizaron y la resignificaron, qué condiciones sociales y/o políticas se modificaron para que ello ocurriese, etc." (p. 14). El sociólogo argentino apuesta por un enfoque que contemple el par situación/actores desde la teoría de la acción social de Touraine y la conceptualización de situación de Antonio Gramsci. En el nivel de situación considera la inestabilidad política, la dependencia y la asistencia externa, y el ejército como institución estatal. En el nivel de los actores toma en consideración la composición social de la oficialidad; las características del ejército como organización, y los aspectos doctrinarios. Los aspectos relacionados a la situación son centrales para explicar el porqué del intervencionismo militar. No obstante, el cómo se hacen las cosas, es decir, las orientaciones de las acciones de gobierno, se entienden introduciendo variables que se refieran a los actores y no ya a la situación (López, 1987, p. 188).

\section{Circulación transnacional}

Diversos trabajos han planteado la importancia de la circulación transnacional de ideas en el proceso de elaboración de las doctrinas de la guerra fría. Podríamos decir que es una perspectiva en ciernes en nuestra región que no ha alcanzado aún el desarrollo de las dos anteriores, no obstante, es posible señalar sus tendencias centrales. Sus supuestos básicos parecen girar en torno a la idea de la existencia de espacios de circulación transnacional de ideas contrasubversivas. En este enfoque, a diferencia de los dos anteriores, el espacio transnacional en el que circulan las ideas cobra centralidad y se erige como un factor clave para pensar las doctrinas militares. No consideran que fueran "impuestas" desde el exterior por la potencia imperial. Tampoco consideran a los procesos sociales, económicos y políticos locales, ni a los actores importadores como los únicos condicionantes en la explicación de la adopción de nuevas ideas doctrinarias.

Esta perspectiva se encuentra estrechamente vinculada al auge de los estudios transnacionales que proponen "un nuevo modo de visualizar las interacciones e intercambios en los niveles hemisférico y global" (Weinstein, 2013, 
p. 4). ${ }^{15}$ Como sugiere Aldo Marchesi (2017), las relaciones entre Estados Unidos y las elites nacionales fueron importantes, pero también existieron otros espacios transnacionales que mediaron entre dichas relaciones y que fueron fundamentales para entender fenómenos tan importantes en la guerra fría como el desarrollismo y la Doctrina de Seguridad Nacional (p. 195). El enfoque de la "circulación transnacional" sí se emparenta con la perspectiva que enfatiza en el proceso "importación-exportación" en cuanto a matizar el carácter determinante que adquiere la disputa Estados Unidos-Unión Soviética respecto de la definición doctrinaria de las Fuerzas Armadas latinoamericanas planteada en la perspectiva de la difusión estadunidense. Esta tercera corriente en ciernes se encuentra enmarcada en los nuevos estudios de la guerra fría en América Latina (Calandra y Franco, 2012; Garrard-Burnett, Lawrence y Moreno, 2013; Marchesi, 2017; Pettiná, 2018; Spenser, 2004; Westad, 2005). Lo característico de este enfoque es que la clave de interpretación del conflicto no está ligada a la competencia entre superpotencias, sino al desarrollo social y político del "Tercer Mundo". Es decir, América Latina (y el resto de lo que se denomina "Tercer Mundo") se ubica como centro -y no como periferia subordinada o mero escenario- de la conflictividad de la época.

Algunos autores han sugerido esta dimensión transnacional para pensar las doctrinas militares. Entre ellos, Gabriel Périès (2009a), quien sostiene que la internacionalización de las doctrinas militares, en cuanto saberes aplicados y resultantes de los conflictos, constituye una de las dimensiones estructurales de las doctrinas militares. Las prácticas, dice el autor, se intercambian y enriquecen al salir de los cuadros nacionales. La "circulación transnacional"

${ }^{15}$ El enfoque de los estudios transnacionales se apoya en dos cuestiones centrales. En primer lugar, remite tanto a una característica del objeto como a una cuestión metodológica. La especificidad de lo "transnacional" como objeto de estudio es su capacidad de circular a través de fronteras nacionales y culturales. Remite así a redes, espacios, ideas, actores cuyos intereses, causas, objetivos, son transversales a la "nación". Al respecto véase el trabajo pionero de Margaret Keck y Kathryn Sikkink (1998) sobre las "Redes Transnacionales de Defensa (RTD)". Por otro lado, lo transnacional remite a una metodología de análisis que pone el foco de atención precisamente en los movimientos, flujos y circulación de gente, ideas y bienes (materiales y simbólicos) a través de dichas fronteras (Zimmermann, 2015). En segundo lugar, pero en estrecha vinculación con lo anterior, los estudios transnacionales vinculados a Latinoamérica parten de una crítica a las teorías del imperialismo, la dependencia y el sistema mundo por su supuesta tendencia a explicar los procesos latinoamericanos -en tanto sociedades periféricas- en función del impacto producido por las naciones del centro. Postulan que las relaciones interamericanas no pueden ser pensadas como una calle de sentido único. Latinoamérica no fue ni es sólo importadora, también ha contribuido a los procesos hemisféricos y globales. 
durante la guerra fría, sostiene, puede ocurrir en el marco de tratados entre Estados, de acuerdos internacionales técnicos de asistencia recíproca entre Fuerzas Armadas, e incluso entre servicios. Sin embargo, a menudo ocurre que varios de estos acuerdos pueden cerrarse totalmente fuera del control o la información directa de las instituciones representativas. Christian Olsson (2009), si bien no analiza el caso latinoamericano, subraya que a partir de los años cincuenta hubo intercambios transnacionales de doctrinas entre Francia, Gran Bretaña y Estados Unidos que perduraron durante todo el periodo de la guerra fría, por medio de consejeros, instructores y oficiales de enlace. Esto dio lugar a una doctrina transnacionalizada. Elie Tenenbaum (2018) afirma que el "espacio americano" aparece, desde los años sesenta, como el receptáculo de las experiencias de esos tres países que reelabora y reafirma. En el campo contrasubversivo, continúa, las ideas circularon tan ampliamente como en el campo opuesto. Ariel Armony (2004), en su segundo trabajo sobre las relaciones entre Argentina y Centroamérica, planteó que la "cruzada argentina en Centroamérica" fue un paso final en la creación de zonas de colaboración y contacto transnacional con distintos tipos de formalización. La situación de Centroamérica estimuló la convergencia de actores dentro de un espacio político transnacional en torno del movimiento armado antisandinista. Armony enfatiza en el interés argentino de llevar adelante la internacionalización de su modelo represivo por el Tercer Mundo con relativa independencia de Estados Unidos. Busca dar cuenta de la capacidad de los países periféricos de actuar con independencia de los superpoderes y de esa forma moldear los conflictos que caracterizaron la guerra fría en la región. Propuso que estas relaciones debían leerse en el marco del proceso de transnacionalización de la violencia politica característico de la guerra fría. La idea de transnacionalización remite, en este caso, a la creación de un espacio político transnacional contrarrevolucionario -como contraparte de las redes transnacionales revolucionariasdonde confluyeron aparatos estatales, elites domésticas y regionales, grupos económicos, organizaciones de la sociedad civil, entre otros. Este espacio, más que geográfico, es un espacio de intercambio y circulación de ideas, vínculos y recursos. Es un espacio ideológico transnacional.

Armony retoma la línea formulada en uno de los libros pioneros dentro del enfoque transnacional, Close encounters of empire: Writing the cultural history of US-Latin American relations, editado por Gilbert Joseph, Catherine LeGrand y Ricardo Salvatore (1998). Esta obra propone una relectura de la historia cultural y de las relaciones entre América Latina y Estados Unidos en la que 
rechazan el modelo "difusionista" vinculado a la noción de "imperialismo cultural" para pensar los intercambios culturales en el continente. La idea de "difusión" identifica un único punto de origen e irradiación de una idea (política, científica, tecnológica, económica) hacia otras zonas. Joseph, LeGrand y Salvatore proponen el concepto de "circulación cultural" retomando la idea de "zonas de contacto" transnacional de la crítica literaria Mary Louise Pratt, para quien las "zonas de contacto" no son sólo lugares de recepción pasiva de determinadas políticas hegemónicas, sino que constituyen ámbitos de multiplicidad de voces, de negociación, préstamo e intercambio.

\section{Circulación-recepción}

Este abordaje es una variante que incorpora aspectos de las dos últimas perspectivas a partir de los conceptos de circulación y recepción retomados de la historia intelectual o los estudios culturales y enfocados desde la sociología histórica, es decir, concebidos como procesos sociales. ${ }^{16}$ Es una síntesis del enfoque conceptual que desarrollé en mi tesis doctoral en la que analicé la circulación de "ideas contrasubversivas" argentinas en Centroamérica y su recepción en la doctrina militar guatemalteca de los años ochenta. A diferencia de los enfoques previos que analizan las ideas de "países centrales" incorporadas en las doctrinas militares latinoamericanas, el abordaje de la circulación-recepción procura pensar la forma en que las ideas doctrinarias "contrasubversivas" circularon entre países latinoamericanos en un momento específico de la guerra fría. Apuesta al anclaje en tiempo-espacio de la circulación y la recepción, premisa fundamental de la sociología histórica (Tilly, 1991). ${ }^{17}$ En este sentido, vale la pena subrayar que las doctrinas militares (y

${ }^{16}$ La noción de proceso alude a creaciones históricas de actores que no deben ser vistas como resultados inevitables de estructuras de las cuales los actores son simples portadores, pero que tampoco se reducen a la creatividad, imaginación o fuerza de los propios actores sociales. La idea de procesos nos remite al comportamiento de actores sociales en escenarios que ellos sólo parcialmente han construido (Torres Rivas, 2004).

${ }_{17}$ Charles Tilly (1991) señaló -en una frase ya clásica- que: "los análisis deberían ser concretos a la hora de referirse a tiempos, lugares y personas reales. Deberían ser históricos para así limitar su alcance a una época definida por el acaecimiento de ciertos procesos claramente definidos, y reconocer desde el comienzo la importancia del tiempo, el cuándo pasan las cosas dentro de una secuencia afecta al cómo ocurren, que toda estructura o proceso constituye una serie de posibilidades de elección (p. 29). 
las ideas externas incorporadas a las mismas) no fueron invariantes durante toda la guerra fría en la región, no hubo "una" DSN o "una" DGR importadas que permanecieron inalterables durante todo el periodo. En mi caso de estudio, por ejemplo, tanto la doctrina militar argentina de mediados de los años setenta como la guatemalteca de principios de los ochenta son doctrinas actualizadas a la dinámica y a los actores de esas coyunturas específicas. ${ }^{18}$ Los guatemaltecos no "combatieron" con la misma doctrina el primer intento revolucionario y el segundo. En los años sesenta la DSN estadunidense fue crucial para enfrentar la insurgencia armada en Guatemala. En los años ochenta, en cambio, las ideas doctrinarias externas no venían del norte sino del sur, y de países extracontinentales como Taiwán (Sala, 2020a). En los años sesenta, la hegemonía estadunidense sobre las fuerzas armadas latinoamericanas era incuestionable, como lo muestra el auge del Sistema Interamericano de Defensa y de la Escuela de las Américas. En los ochenta, el panorama había cambiado. El quiebre de los vínculos de las dictaduras y gobiernos militares latinoamericanos con el gobierno de James Carter (1976-1981), el desplome del sistema militar hemisférico, y el devenir de la crisis centroamericana, posibilitaron una reconfiguración de las relaciones entre las fuerzas armadas latinoamericanas y la emergencia de un proceso de colaboración "contrasubversiva" (1978-1982) entre las dictaduras institucionales de las Fuerzas Armadas de Sudamérica y los gobiernos militares y las dictaduras de América Central (Sala, 2020b, p. 26). En este proceso, además de prácticas de coordinación represiva, acciones coordinadas para hacer frente a las acusaciones por violación a los derechos humanos y venta de armas, también fue importante la circulación de ideas y aspectos doctrinarios "contrasubversivos" (Sala, 2020b). Las ideas fluyeron a través de la circulación de bibliografía, la realización de cursos de distinto tipo en las escuelas militares latinoamericanas y conferencias varias. ${ }^{19}$

${ }^{18}$ Para el caso argentino, véase Jemio (2013), y para el caso guatemalteco, Sala (2020a, 2020b)

${ }^{19}$ Entre 1975 y 1983, los guatemaltecos, por ejemplo, realizaron cursos en muchos países de América Latina mientras su participación en la Escuela de las Américas llegó a ser nula en los años transcurridos entre 1978 y 1981. Según las memorias de labores del ministerio de defensa guatemalteco, las Órdenes Generales del Ejército para Oficiales y diversos documentos de archivo, como las fichas de ascenso de oficiales del Estado Mayor Presidencial, los guatemaltecos realizaron cursos en Venezuela, Colombia, Uruguay, Argentina, México, Honduras, Brasil y Perú. El detalle de los cursos que tomaron se encuentra en Sala (2020b, pp. 273-279). Por otro lado, la bibliografía citada en las tesis de ascenso de oficiales en estos años corresponde 
Ese anclaje en tiempo-espacio permite argumentar que en la última fase de la guerra fría en la región, la forma en que las ideas se movieron no fue la de "difusión", ni la "importación" en el nivel nacional, sino la circulación de ideas "contrasubversivas" entre varias fuerzas castrenses latinoamericanas, especialmente entre aquellas que aún argumentaban estar "luchando contra la subversión". En esta línea, la propuesta centrada en la "circulación-recepción" recupera de la perspectiva que enfatiza en la circulación transnacional de las doctrinas militares la importancia, en la coyuntura 1978-1982, del espacio transnacional entendido en menor medida como zona de influencia, difusión o coerción que como espacio de contacto, red, colaboración, negociación. Lo que nos interesa remarcar es la circulación de "ideas contrasubversivas" como un proceso regional en esta fase de la guerra fría, por ello privilegiamos las ideas de circulación-recepción más que "importación-exportación" en la que la relación se limita a dos actores nacionales: quien importa y quien exporta.

Una de las características del proceso de colaboración "contrasubversiva" (1978-1982) al que aludimos previamente es la relevancia que cobran las autonomías de las fuerzas castrenses de la región respecto del gobierno estadunidense de James Carter (1976-1981) y la colaboración entre ellas. De hecho, a fines de los años setenta, los acontecimientos en América Latina, especialmente en Centroamérica, estaban más vinculados a la dinámica del "Tercer Mundo" movilizado por una ola de revoluciones, empezando por Vietnam, Angola, Mozambique, Etiopía, Irán, Granada y Nicaragua, que al enfrentamiento entre Estados Unidos y la URSS. En esta perspectiva, al igual que en las que enfatizan en la "circulación transnacional" o la "importación-exportación”, la guerra fría, entendida como contienda entre las dos grandes potencias, pierde peso y la dinámica conflictiva del "tercer Mundo" adquiere protagonismo.

Ahora bien, en tanto la dinámica no es la de "difusión", con meros receptores pasivos, la circulación de ideas nada dice respecto de los modos de adecuación de las ideas externas a las doctrinas locales, de la forma en que dichas ideas fueron recibidas o del uso que se hizo de ellas. En este sentido, la propuesta recupera la importancia de las mediaciones a la que apuesta el enfoque que enfatiza en el proceso de exportación-importación. En este caso, creemos conveniente sostener la idea de recepción frente a la de impor-

a fuerzas armadas sudamericanas y de países extracontinentales como Taiwán y en menor medida a Estados Unidos (Sala, 2020a). 
tación dado que la primera tiene la ventaja de resaltar la apropiación crítica en el proceso (Fernando H. Cardoso, 1977; Dotti, Blanco, Plotkin, Vezzetti y García, 2008; Jauss, 2013; Tarcus, 2007, entre otros), mientras que la segunda -vinculada al mercado y a la circulación internacional de mercancías- indica más bien la adopción como un todo. ${ }^{20}$ Según Horacio Tarcus (2007), la recepción es uno de los momentos del proceso global de producción y circulación de ideas; momento que define la expansión de un cuerpo de ideas a un campo de producción diverso del original desde el punto de vista del sujeto receptor. La recepción sugiere más que reproducción automática, cierta "originalidad de la copia" como sugirió tempranamente Fernando H. Cardoso (1977). Para Dotti et al. (2008), "receptar y concretizar discursos que se originan en otros ámbitos es siempre un gesto original", y sostiene, incluso, que "toda idea receptada es necesariamente tan local como la comprensión y uso -argumentativo, retórico y/o político- que de ella se ensaya" (p. 98). La "creatividad" que sugiere el concepto de recepción debe leerse -desde la sociología históricaen función de sus condicionantes, es decir, en conexión con el entramado social en el que se insertan los actores. En esa línea, Pierre Bourdieu (2017) subraya la necesidad de atender a las necesidades dictadas por el "campo de recepción" para comprender la reinterpretación local de las ideas que circulan internacionalmente (p. 161). Para explicar el proceso de recepción, entonces, es clave indagar en el sujeto de la recepción, en quién recibe, sus intereses y relaciones de poder dentro de su campo; y por otro lado, es necesario indagar en la coyuntura de la recepción. Desde otro universo conceptual, como sugirió Ernesto López (1987), en el par situación/actor. Ambas dimensiones permiten explicar el porqué y el cómo de la recepción. En este punto, al igual que los trabajos que enfatizan en el proceso de importación-exportación, se busca pensar lo ideológico, no como un campo autosuficiente sino en conexión con los procesos políticos, sociales y económicos internos. ${ }^{21}$

${ }^{20}$ Las mercancías, como tales, permanecen inmutables, aunque cambie la valorización social de las mismas; mientras que las ideas cambian y lo hacen en virtud del entramado relacional en el que se insertan.

${ }^{21}$ A modo de ejemplo, en mi investigación argumenté que los guatemaltecos afianzaron a través de la recepción de las ideas argentinas un enfoque político-ideológico de la "guerra contrasubversiva" cuyo eje gira en torno a la idea de que la causa principal del conflicto es ideológica y no económica vinculada al subdesarrollo, como sostenía la DSN en los años sesenta. Desde esa mirada, cercana a la DGR francesa, la subversión había llevado adelante una fuerte ideologización sobre la población y ello explicaba el conflicto. El fin de la guerra contrasubversiva, entonces, era disputar y ganar las "mentes y corazones" de la población. Para ello, las políticas 


\section{REFLEXIONES FINALES}

Las ideas externas han sido una parte importante de las doctrinas militares latinoamericanas durante la guerra fría y así lo sugieren todos los estudios sobre las mismas. Se puede afirmar que esa dimensión de las doctrinas militares debe considerarse en su definición conceptual.

Lo más estudiado ha sido la adopción de la DSN estadunidense o la DGR francesa, es decir, las ideas de "países centrales" recibidas por los latinoamericanos. La forma de abordar esa incorporación de ideas externas, sin embargo, no ha sido sistematizada o teorizada, aunque la literatura parte de supuestos al respecto que pueden agruparse a partir de las ideas de "difusión", "exportación-importación", "circulación transnacional". Cada perspectiva parte de una noción de "doctrina militar" y una concepción de los orígenes de las ideas que le dan forma; de la forma en que circularon en la región, y los modos de adecuación de las mismas a las doctrinas locales. Como fuimos

represivas no alcanzaban. Hacía falta desplegar la "dimensión productiva", es decir, construir adhesión, consenso, apoyo y participación; y negárselos a la subversión. La importancia de la acción psicológica sobre las masas fue uno de los aspectos más destacados de la recepción. Si consideramos al sujeto que recibe y las condiciones sociales en las que lo hace, la recepción guatemalteca se explica por los siguientes factores: en principio, por el hecho de que la misma se llevó adelante como parte del proceso de profesionalización impulsado por el Centro de Estudios Militares (CEM), entre cuyos objetivos se encontraba el desarrollo de una doctrina propia. En ese proceso, los oficiales profesionalistas nucleados en el CEM -en su disputa con los "oficiales guerreros"- incorporaron ideas de otras fuerzas armadas, entre las que destacan las argentinas. Esas ideas fueron recibidas en una coyuntura caracterizada por dos aspectos centrales: el auge sin precedentes de las organizaciones revolucionarias con características diferentes a las guerrillas de los años sesenta, no sólo por su magnitud sino también porque las masas indígenas se erigían en el centro del conflicto; y un aislamiento creciente del gobierno militar guatemalteco tanto en el ámbito local como internacional. Ambas cuestiones llevaron a los estratégicos o profesionalistas a plantear la posibilidad de perder la guerra. Las ideas que pregonaban los argentinos respecto de la "fuerte catequización ideológica" que había realizado la subversión sobre la población en América Latina, y la campaña de acusación a los militares, a escala internacional, por las violaciones a los derechos humanos, cobraban sentido ante el levantamiento de la población indígena y la pérdida de apoyos al gobierno en todos los frentes. Por último, el golpe de Estado de 1982 en el marco de una crisis aguda reposiciona en puestos clave al sector estratégico o profesionalista y su enfoque doctrinario sobre la "guerra contrasubversiva”, el que incorporaba el enfoque político-ideológico construido a partir de la recepción de ideas argentinas. Ello permite la elaboración oficial de una doctrina -más que a partir de elementos provenientes de una única fuente, Estados Unidos-a través de la sistematización de las ideas de seguridad nacional y de la propia experiencia contraguerrillera de los años sesenta y de la recepción de ideas de las fuerzas armadas de la región, siendo las argentinas centrales en dicho proceso. 
indicando a lo largo del texto, estas diferencias evidencian supuestos divergentes respecto de, por un lado, la forma en que se concibe al actor militar, a sus vínculos con otras fuerzas armadas y a sus relaciones con la sociedad de la que forman parte; en segundo lugar, de la manera en que entienden los procesos de circulación de ideas y, finalmente, de la concepción de la guerra fría en la que abrevan y de los vínculos internacionales desatados en este contexto. La perspectiva de la "difusión norteamericana" difiere de las otras en las tres dimensiones indicadas. Mientras que las perspectivas de "importación-exportación", "circulación transnacional" y "circulación-recepción" abrevan en supuestos similares en torno a la guerra fría y validan los intereses y características internas del actor militar, pero se diferencian en la forma de concebir el proceso de circulación de las ideas doctrinarias. No obstante, si tomamos las tres dimensiones de manera articulada y como una totalidad -como consideramos debe hacerse en este caso- podemos sostener la idea de perspectivas epistemológicas diversas.

Finalmente, interesa subrayar de cada perspectiva algunos aspectos favorables $y$ otros que pueden resultar problemáticos a la hora de estudiar las doctrinas militares. Los estudios reunidos en lo que llamamos el enfoque de la "difusión norteamericana" -uno de los más generalizados- se preocuparon por el origen de las ideas y así lograron mostrar con claridad la política estadunidense de los años sesenta para la región y valorar la enorme significación que tuvo entre las instituciones armadas del sur, pero opacó otros aspectos de relevancia como la convergencia de las ideas externas con las producciones ideológicas nacionales, los procesos internos a las fuerzas armadas latinoamericanas o los objetivos con que los actores locales "recibieron" la propuesta ideológica de la seguridad nacional estadunidense. Las Fuerzas Armadas latinoamericanas pierden capacidad de agencia en esta mirada. En el otro extremo, la perspectiva que enfatiza en la "circulación transnacional" resalta los espacios de circulación transnacional de las doctrinas militares contrasubversivas desdibujando los orígenes de las mismas. Ello puede resultar -si no se tiene en cuenta la dinámica histórica de los vínculos transnacionalesen la pérdida de consideración de las relaciones de poder en ese nivel. Este enfoque, no obstante, abre posibilidades de indagar en otras ideas y espacios de circulación (y otros actores) en el proceso de elaboración de las doctrinas militares que no han sido estudiados con profundidad. Permite hipotetizar, incluso, sobre la existencia de una "cultura militar regional", como sugirió Ariel Armony. Sin embargo, ello no explica los usos, adaptaciones y manifes- 
taciones locales de las ideas y este enfoque nada dice al respecto. Estos aspectos son abordados por la perspectiva de la "importación-exportación" y por la que proponemos en este texto nombrada como "circulación-recepción". En ambas, se recupera la importancia de las mediaciones, la centralidad del actor militar local, y la complejidad del contexto para explicar la incorporación de ideas externas en las doctrinas locales. En la primera, la indagación se centró en la importación o exportación de ideas entre las Fuerzas Armadas de países centrales y las latinoamericanas. La segunda, y en virtud de la disponibilidad de nuevas fuentes oficiales, permite valorar la importancia que la circulación de ideas entre "países periféricos" tuvo en la elaboración de la(s) doctrinas militares durante momentos específicos de la guerra fría. Ello sugiere que las doctrinas militares en los países latinoamericanos fueron dinámicas y cambiantes, que no hubo una doctrina de seguridad nacional, sino doctrinas que fueron adquiriendo nuevas configuraciones a medida que la dinámica del proceso de enfrentamientos, luchas y conflictos locales iba variando y que los vínculos externos se reconfiguraban.

Resta aclarar que la reconstrucción de los estudios sobre doctrinas militares que proponemos en este trabajo constituye una de las tantas posibles, y obedece a la orientación de la propia perspectiva y al modo de inserción que buscamos en el campo de estudios sobre las relaciones entre las Fuerzas Armadas en la región durante la guerra fría. Esperamos que aporte al debate y dispare nuevas reflexiones.

\section{LISTA DE REFERENCIAS}

Adams, R. N. (1968). The development of the Guatemalan military. Studies in Comparative International Development, 4(5), 91-110.

Adams, R. N. (1973). Crucifixion by power: Essays on Guatemalan National Social Structure, 1944-1966. Austin y Londres: University of Texas Press.

Aguilera Peralta, G. (1989). El fusil y el olivo. La cuestión militar en Centroamérica. San José: FlACSO/DEI.

Amaral, S. (1998). Guerra revolucionaria: de Argelia a la Argentina, 1957-1962. Investigaciones y Ensayos, 48, 173-195.

Armony, A. (1999). La Argentina, los Estados Unidos y la cruzada anticomunista en América Central, 1977-1984. Bernal: Universidad Nacional de Quilmes. 
Armony, A. (2004). Transnacionalizando la "guerra sucia": Argentina en Centroamérica. En D. Spenser (comp.), Espejos de la guerra fría: México, América Central y El Caribe (pp. 319-348). México: CIESAs/sRe/Miguel Ángel Porrúa.

Bonavena, P. y Nievas, F. (2006). Las nuevas formas de la guerra, sus doctrinas y su impacto. FERMENTUM, 16(46), 355-371. Recuperado de http://www.saber.ula. ve/handle/123456789/20738

Bourdieu, P. (2017). Las condiciones sociales de la circulación internacional de las ideas. En Intelectuales, política y poder (pp. 159-170). Buenos Aires: Eudeba.

Buchrucker, C. (1994). Las formas autoritarias del nacionalismo y el conservadurismo latinoamericanos. Ciclos, IV(1941), 189-212.

Bustamante, F. (1986). Los paradigmas en el estudio del militarismo en América Latina. Documentos de Trabajo. Santiago de Chile: Flacso.

Calandra, B. y Franco, M. (2012). La guerra fría cultural en América Latina. Desafíos y límites para una nueva mirada de las relaciones interamericanas. Buenos Aires: Biblos.

Calvo, R. (1979). La doctrina militar de la seguridad nacional. Autoritarismo político y neoliberalismo económico en el Cono Sur. Caracas: Universidad Católica Andrés Bello.

Canelo, P. (2008). El proceso en su laberinto. La interna militar de Videla a Bignone. Buenos Aires: Prometeo.

Cardoso, F. H. (1977). La originalidad de la copia: la CEPAL y la idea de desarrollo. Revista de La CEPAL, 4, 7-39.

Chateau, J. (1983). Seguridad nacional y guerra antisubversiva. Santiago de Chile: Flacso-Chile. Recuperado de http://flacsochile.org/biblioteca/pub/memoria/1983/001028.pdf

Cherñavsky, M. (1993). La seguridad nacional y el fundamentalismo democrático. Buenos Aires: Centro Editor de América Latina.

Comblin, J. (1976). La doctrina de la Seguridad Nacional. Revista Mensaje, 25(247), 96-104.

Comblin, J. (1978). El poder militar en América Latina. Salamanca: Ediciones Sígueme.

Comblin, J. (1979). La Doctrina de la Seguridad Nacional. En Dos ensayos sobre seguridad nacional (pp. 9-191). Santiago de Chile: Arzobispado de Santiago-Vicaría de la Solidaridad (Colección Estudios, núm. 6).

Costa Pinto, L. A. (1972). Nacionalismo y militarismo. México: Siglo XXI.

Dixon, P. (2012). The British approach to counterinsurgency: From Malaya and Northern Ireland to Iraq and Afghanistan. London: Palgrave Macmillan.

Dotti, J., Blanco, A., Plotkin, M., Vezzetti, H., García, L. I. (2008). Encuesta sobre el concepto de recepción. Políticas de La Memoria, 8/9, 98-109. Recuperado de https:// ojs.politicasdelamemoria.cedinci.org/index.php/PM/article/view/428/402 
Drouin, M. (2017). Permitir que solamente la buena planta crezca. La guerra contrasubversiva guatemalteca y sus raíces francesas. En R. García Ferreira y A. Taracena Arriola (comps.), La guerra fría y el anticomunismo en Centroamérica. Guatemala: Flacso.

Finchelstein, F. (2016). Orígenes ideológicos de la "guerra sucia". Fascismo, populismo y dictadura en la Argentina del siglo xx. Buenos Aires: Sudamericana.

Fitch, J. S. (1977). The political consequences of US military assistance to Latin America. Carlisle Barracks: US Army War College. Recuperado de https://apps.dtic.mil/ dtic/tr/fulltext/u2/a047590.pdf

Fox, C. T. (2001). The U.S. army school of the Americas and U. S. national interests in the 20th century. State University. Recuperado de http://scholar.lib.vt.edu/theses/ available/etd-05022001-\%5Cn153035/unrestricted/FoxThesis.pdf

García, A. (1991). La Doctrina de la Seguridad Nacional (1958-1983) (vols. I y II). Buenos Aires: Centro Editor de América Latina (CEAL).

García, P. (2005). El genocidio de Guatemala a la luz de la sociología militar. Madrid: Sepha. Versión online: https://www.derechoshumanos.net/libros/GenocidioGuatemala.htm

Garrard-Burnett, V., Lawrence, M. A. y Moreno, J. E. (2013). Beyond the eagle's shadow: New histories of Latin America's cold war. Nuevo México: University of New Mexico Press.

Garretón, M. A. (1978). De la seguridad nacional a la nueva institucionalidad. Notas sobre la trayectoria ideológica del nuevo Estado autoritario. Revista Mexicana de Sociología , 40(4), 1259-1282. Dor: https://doi.org/10.2307/3539657

Garretón, M. A. y Arriagada Herrera, G. (1978). Doctrina de Seguridad Nacional y régimen militar. Estudios Sociales Centroamericanos, 20 y 21.

Gill, L. (2004). The school of the Americas. Military training and political violence in the Americas. Durham/Londres: Duke University Press.

Imaz, J. L. de (1964). Los que mandan. Buenos Aires: Eudeba.

Jauss, H.-R. (2013). Historia de la literatura como provocación. Madrid: Gredos.

Jemio, A. S. (2013). La construcción del enemigo interno en los reglamentos del Ejército argentino de las décadas del sesenta y setenta. Continuidades y rupturas. Ponencia presentada en las X Jornadas de Sociología, Facultad de Ciencias Sociales, Universidad de Buenos Aires.

Joffily, M. (2008). No centro da engrenagem. Os interrogatórios na Operação Bandeirante no DoI de São Paulo (1969-1975). (Tesis de doctorado). Universidade de São Paulo, Brasil. 
Joseph, G. M., LeGrand, C. y Salvatore, R. (1998). Close encounters of empire. Writing the cultural history of U. S.-Latin American relations. Durham/Londres: Duke University Press.

Keck, M. y Sikkink, K. (1998). Activists beyond borders: Advocacy networks in international politics. Ithaca, NY: Cornell University Press.

Klare, M. T. (1990). El ímpetu intervencionsita: la doctrina militar estadounidense de la Guerra de Baja Intensidad. En M. T. Klare y P. Kornbluh (coords.), Contrainsurgencia, proinsurgencia y antiterrorismo en los 80 . El arte de la guerra de baja intensidad (pp. 65-104). México: Grijalbo.

Klare, M. T. y Kornbluh, P. (coords.). (1990). Contrainsurgencia, proinsurgencia y antiterrorismo en los 80. El arte de la Guerra de Baja Intensidad. México: Grijalbo.

Kornbluh, P. (1990). Nicaragua: la guerra proinsurgente de Estados Unidos en contra de los sandinistas. En M. T. Klare y P. Kornbluh (coords.), Contrainsurgencia, proinsurgencia y antiterrorismo en los 80. El arte de la Guerra de Baja Intensidad (pp. 179-206). México: Grijalbo.

Leal Buitrago, F. (2002). La seguridad nacional a la deriva: del Frente Nacional a la posguerra fría. Colombia: Alfaomega/ceso/Flacso Ecuador.

Leal Buitrago, F. (2003). La Doctrina de Seguridad Nacional: materialización de la guerra fría en América Latina. Revista de Estudios Sociales, 15, 74-87. Dor: https:// doi.org/0123-885X

Llumá, R. D. (2003). Influence de la Mission d'assesseurs militaires français spécialistes en guerre contre révolutionnaire, dans la formation des officiers argentins pendant la période 1957-1970. Université de Paris III-Sorbone Nouvelle.

López, E. (1985). Doctrinas militares en Argentina: 1932-1980. En C. Moneta, E. López y A. Romero, La reforma militar (pp. 103-143). Buenos Aires: Legasa.

López, E. (1987). Seguridad nacional y sedición militar. Buenos Aires: Legasa.

Lozada, S. M., Viaggio, J., Zamorano, C. y Barcesat, E. (1985). Inseguridad y desnacionalización: la "doctrina" de la seguridad nacional. Buenos Aires: Ediciones Derechos del Hombre.

Maira, L. (1990). El Estado de la Seguridad Nacional en América Latina. En P. González Casanova (coord.), El Estado en América Latina. Teoría y práctica (pp. 108-130). Buenos Aires: Siglo XXI/UnU.

Marchesi, A. (2017). Escribiendo la guerra fría latinoamericana: Entre el sur "local" y el norte "global". Estudios Históricos, 30(60), 187-202. DoI: https://doi.org/10.1590/ S2178-14942017000100010 
Martins Filho, J. R. (2008). A influência doutrinária francesa sobre os militares brasileiros nos anos de 1960. Revista Brasileira de Ciências Sociais, 23(67), 39-50. Recuperado de http://www.scielo.br/pdf/rbcsoc/v23n67/04.pdf

Martins Filho, J. R. (2012). A conexão francesa: da Argélia ao Araguaia. Varia Historia, 28(48), 519-536. DoI: https://doi.org/10.1590/S0104-87752012000200003

Mazzei, D. (2002). La misión militar francesa en la Escuela Superior de Guerra y los orígenes de la guerra sucia, 1957-1962. Revista de Ciencias Sociales, 13, 105-137.

Methol Ferré, A. (1979). Sobre la actual ideología de la Seguridad Nacional. En Dos ensayos sobre Seguridad Nacional (pp. 207-231). Santiago de Chile: Arzobispado de Santiago, Vicaría de la Solidaridad (Colección Estudios, núm. 6).

Míguez, M. C. (2013). ¿Anticomunistas, antiestatistas, antiperonistas? La "nacionalización” de la Doctrina de Seguridad Nacional en la Argentina y la legitimación del golpe de Estado de 1966. Revista SAAP, 7(1), 65-95. Recuperado de https:// revista.saap.org.ar/articulos/revista-saap-volumen-7-1.html

Molinari, L. (2011). Las elites salvadoreñas y la Doctrina de Seguridad Nacional en los 60. Boletín de La AFEHC, Asociación para el Fomento de los Estudios Históricos en Centroamérica, 49. Recuperado de https://www.academia.edu/11677459/Las_elites_salvadoreñas_y_la_Doctrina_de_Seguridad_Nacional_en_los_60

Monkman, G. (1992). The institutionalization of Doctrine of National Security in Argentina: the military foreign policy. Virginia: University of South Carolina.

Nabuco de Araujo, R. (2011). Conquête des esprits et commerce des armes: la diplomatie militaire française au Brésil (1945-1974). Le Mirail: Université de Toulouse 2. Recuperado de https://tel.archives-ouvertes.fr/tel-00690336

Nabuco de Araujo, R. (2012). L'art français de la guerre. Transferts de la doctrine de la guerre révolutionnaire au Brésil (1958-1974). Cahiers des Amériques Latines, 7, 39-58. DOI: https://doi.org/10.4000/cal.2339

Nabuco de Araujo, R. (2016). La coopération entre les services de renseignement français et brésilien (1964-1975) : contre-révolution, anticommunisme et répression. Nuevo Mundo Mundos Nuevos. DoI: https://doi.org/10.4000/nuevomundo.68873

Nina, A. (1979). La Doctrina de Seguridad Nacional y la integración latinoamericana. Nueva Sociedad, 27, 33-50.

Nun, J. (1966). América Latina: la crisis hegemónica y el golpe militar. Desarrollo Económico, vI.

Nunn, F. (1976). The military in Chilean history: Essays on civil-military relations, 18101973. Albuquerque: University of New Mexico Press. 
Olsson, C. (2009). ¿Guerra total y/o fuerza mínima? Historia y paradojas de "los corazones y los espíritus". Cultures \& Conflits. Recuperado de https://journals.openedition.org/conflits/17286

Périès, G. (1999). De l'action militaire à l'action politique. Impulsion, codification et application de la doctrine de la "guerre révolutionnaire" au sein de l'Armée française (1944-1960). (Tesis de doctorado). Université de Paris I.

Périès, G. (2009a). De Argelia a la Argentina: estudio comparativo sobre la internacionalización de las doctrinas militares francesas en la lucha antisubversiva. Enfoque institucional y discursivo. En I. Izaguirre (comp.), Lucha de clases, guerra civil y genocidio en la Argentina, 1973-1983: antecedentes, desarrollo, complicidades (pp. 391-421). Buenos Aires: Eudeba.

Périès, G. (2009b). La doctrina militar contrainsurgente como fuente normativa de un poder de facto exterminador basado sobre la excepcionalidad. En D. Feierstein, Terrorismo de Estado y genocidio en América Latina (pp. 221-248). Buenos Aires: Prometeo Libros/Programa de las Naciones Unidas para el Desarrollo.

Pettiná, V. (2018). Historia mínima de la guerra fría en América Latina. México: El Colegio de México.

Pion-Berlin, D. (1989). Latin American National Security Doctrines: Hard and softline themes. Armed Forces \& Society, 15(3), 411-429. DoI: https://doi. org/10.1177/0095327X8901500305

Pontoriero, E. D. (2017). La seguridad interna como "teatro de guerra": estado de excepción y contrainsurgencia en la Argentina (1955-1976). (Tesis de doctorado inédita). Universidad Nacional de San Martín, Argentina.

Potash, R. A. (1985). El ejército y la política en la Argentina (I) 1928-1945. De Yrigoyen a Perón. Buenos Aires: Hyspamérica.

Potash, R. A. (1986). El ejército y la política en la Argentina (II) 1945-1962. De Perón a Frondizi. Buenos Aires: Hyspamérica.

Ranalletti, M. (2011). Una aproximación a los fundamentos del terrorismo de Estado en la Argentina: la recepción de la noción de "guerra revolucionaria" en el ámbito castrense local (1954-1962). Anuario del Centro de Estudios Históricos "Prof. Carlos S. A. Segreti”, 11(11), 261-278.

Ranalletti, M. (2018). Réexaminer la question de l'implantation de la "doctrine de la guerre révolutionnaire” en Argentine. Histoire@Politique, 34. Recuperado de www. histoire-politique.fr

Rid, T. y Keaney, T. (eds.) (2010). Understanding counterinsurgency: Doctrine, operations, and challenges. Nueva York: Routledge. 
Robin, M.-M. (2014). Escuadrones de la muerte. La escuela francesa. La Plata: De la Campana.

Rojas, J. y Viera-Gallo, J. A. (1977). La Doctrina de Seguridad Nacional y la militarización de la política en América Latina. Revista Chile-América, 28-30.

Rouquié, A. (1981). Poder militar y sociedad política en la Argentina. (vol. I hasta 1943). Buenos Aires: Emecé Editores.

Rouquié, A. (1982). Poder militar y sociedad política en la Argentina. (vol. II. 1943-1973). Buenos Aires: Emecé Editores.

Ruz, M. (1977). Doctrina de Seguridad Nacional. Contribución a un debate. Revista Mensaje 26(261), 418-426.

Sala, L. (2020a). En búsqueda de una doctrina contrasubversiva propia. Las tesis de ascenso de los oficiales guatemaltecos, 1975-1985. Revista Desafíos, 32(2).

Sala, L. (2020b). La guerra es ideológica. La circulación de ideas "contrasubversivas" argentinas y su recepción en la doctrina militar guatemalteca, 1977-1982. (Tesis de doctorado inédita). Facultad de Ciencias Sociales, Universidad de Buenos Aires. Argentina.

Sala, L. (en prensa). La Doctrina de Seguridad Nacional en América Latina. Un repaso por los estudios clásicos y sus críticos. e-l@tina.

Shirley, S. L. (1997). The impact of US security assistance on democracy in Latin America: the case of Guatemala during the 1960s. (Dissertation). University of Texas.

Siegel, D. y Hackel, J. (1990). El Salvador: la nueva visita de la contrainsurgencia. En K. Michael T. y P. Kornbluh (coords.), Contrainsurgencia, proinsurgencia y antiterrorismo en los 80. El arte de la guerra de baja intensidad (pp. 147-178). México: Grijalbo.

Soprano, G. (2018). El ejército argentino y la guerra convencional en la segunda mitad del siglo xx. Reflexiones a partir de la experiencia de la artillería en la guerra de Malvinas. Contenciosa, 8.

Spenser, D. (coord.) (2004). Espejos de la guerra fría: México, América Central y el Caribe. México: ciesAs/Miguel Ángel Porrúa.

Stepan, A. (1971). The military in politics. Changing patterns in Brazil. Princeton: Princeton University Press.

Stepan, A. (1973). The new professionalism of internal warfare and military role-expansion. En A. Stepan (ed.), Authoritarian Brazil. New Haven: Yale University Press.

Stepan, A. (1978). The State and society: Peru in comparative perspective. Princeton: Princeton University Press.

Tapia Valdés, J. (1980). El terrorismo de Estado. La Doctrina de la Seguridad Nacional en el Cono Sur. México: Nueva Imagen. 
Tarcus, H. (2007). Marx en la Argentina. Sus primeros lectores obreros, intelectuales y científicos (1871-1910). Buenos Aires: Siglo XXI.

Tenenbaum, É. (2018). Coopération et rivalités occidentales dans la lutte antisubversive en Amérique Latine et aux Caraïbes (1959-1969). Histoire@Politique, 34. Recuperado de www.histoire-politique.fr

Tilly, C. (1991). Grandes estructuras, procesos amplios, comparaciones enormes. Madrid: Alianza Editorial.

Torres-Rivas, E. (2001). América Central desde 1930: perspectiva general. En L. Bethell, Historia de América Latina (T. 14). Barcelona: Crítica.

Torres-Rivas, E. (2004). Los caminos hacia la democracia política en América Central. En D. Achard y L. González (ed.), Un desafío a la democracia. Los partidos políticos en Centroamérica, Panamá y República Dominicana (pp. 149-178). San José, Costa Rica: ABC Ediciones.

Velásquez Rivera, É. D. J. (2002). Historia de la Doctrina de la Seguridad Nacional. Convergencia, 27, 11-39.

Veneroni, H. (1973). Estados Unidos y las Fuerzas Armadas de América Latina. La dependencia militar. Buenos Aires: Ediciones Periferia.

Villanueva, V. (1972). El CAEM y la revolución en la Fuerza Armada. Lima: Instituto de Estudios Peruanos.

Weinstein, B. (2013). Pensando la historia más allá de la nación: la historiografía de América Latina y la perspectiva transnacional. Aletheia, 3(6). Recuperado de http://www.memoria.fahce.unlp.edu.ar/art_revistas/pr.6118/pr.6118.pdf

Westad, O. A. (2005). The global cold war: third world interventions and the making of our times. Nueva York: Cambridge University Press.

Wolpin, M. D. (1973). Military indoctrination and United States imperialism. Nueva York: State University College.

Zavaleta Mercado, R. (2015). Problemas de la determinación dependiente y la forma primordial. En La autodeterminación de las masas (pp. 291-320). Buenos Aires: ClACSO.

Zimmermann, E. (2015). Estudio introductorio. Una nota sobre nuevos enfoques de historia global y transnacional. Estudios Sociales del Estado, 3(5), 12-30. Recuperado de http://hdl.handle.net/2133/16761 